\title{
Reflections of Digitalization on Painting
}

\author{
Aydoğan D. 1 \\ 1Derya Aydoğan, Yıldız Technical University, (Turkey) \\ e-mail: derya_aydgn@hotmail.com
}

\begin{abstract}
New media has provided diversity in art in terms of medium and tools. Art has entered a new period with collective production processes and forms. Different techniques, applications, production and sharing forms have emerged with digitization in painting. With the multi-faceted structure of art in digital environment, painting has become more disciplinary compared to previous periods, and has become closer to different fields and branches of art. In addition to traditional painting practices, the ability to create digital images has brought a different perspective to the art of painting. On the other hand, digital artists that emerged in response to traditional artists have expanded their production methods to a wider range. In addition to the innovations in production, as new issues in the presentation methods have an impact on the arts, new discussion issues have risen. Furthermore, it can be thought that the definition of art creates confusion due to the diversity and intensity of production in the digital environment. Reproduction, duplication and modification of a work of art for different purposes bring the issues of quality, quantity and aesthetics into question. In this study, the state of the art of painting will be examined based on the production and presentation forms in digital media.
\end{abstract} Digitalization.

\section{Introduction}

In today's world, where everyone with internet access is connected to each other via networks, technology is inevitably advancing at a great speed. Surrounded by digital networks, people are in an environment in which they can communicate, learn from each other, contribute to and improve their work without any problem of distance and space. With this ease of interaction, technology is progressing much faster than the past. Nowadays, changes and transformations are experienced in all areas that can establish a connection with technology. Branches of art are also affected by this situation. One of the areas affected by computer-based technology is painting. Painting is a field that emerged as a form of communication and transformed into an art form throughout history. The materials have diversified and different movements have emerged in time and paintings have been produced using different techniques. Today's creations in digital media are quite different in terms of the environment they have been created in, and the tools and techniques used in the process.

Produced in digital media with technological means, painting has become more interdisciplinary by establishing close connections with fields like graphic design and photography. In this context, painting produced in digital media opens up a new period for artists, which can be considered as an innovation. The artist can produce richer works compared to traditional painting within the extent of his or her imagination. This independent practice in painting that pushes the limits has changed the traditional understanding of painting. In this sense, it is clear that painting practices will lead to a great transformation, as the number of people born before the digital era in the future decreases and the people of the digital age increase. However, depending on how new technologies are used, this situation raises questions such as whether they will interrupt the progress of the art of painting, destroy it or provide a more unlimited space.

\section{Literature}

The electronic revolution has radically changed all spheres of life and has made the term "digital" a hot topic. However, as explained by Yaylagül, the period from the development of language 
and word in the history of humanity to the development of today's complex electronic and digital mass communication systems is not as straight and linear as the evolutionist approach claims. The history of humanity is a complex and dialectical process of leaps in which quantitative developments lead to qualitative transformations through social revolutions at certain points. (Yaylagül, 2013: 18) From this point of view, it can be said that the transformation of the digital process in the art world has brought some leaps and great innovations.

The Internet, which is developed by multiple computers connecting to each other to create an international communication network, is constantly changing and transforming "things", with is everexpanding structure that feeds on people, societies and fields. In fact; summarized from a study; (Aydoğan, 2014: 48-49) the Internet, which dates back to the Cold War years between the US and the Soviet Union in the 1950s, was created with a unit called ARPA (Advanced Research Projects Agency) within the Ministry of Defense to make communication in military easier. ARPA was then transformed into DARPA (The Defense Advanced Research Project Agency) to develop systems against guided missiles during the Cold War. This unit made efforts to support military projects by connecting computers far from each other. In 1969, four computers transmitted information for the first time: three in California (Los Angeles-Santa Barbara-Stanford) and one in Utah (Salt Lake City). The next stage was the development of ARPANET, the first computer network. With this development, computers were able to communicate among themselves, and information could be exchanged between long distances with relatively high speed. Studies were conducted on new network systems that could work faster over time. "WWW" (World-Wide-Web) was developed and presented to the Internet users. It was now possible to navigate between pages and upload graphics. After serving the military, the Internet spread to the academic circles, then to the general public. Data transfer, sharing and access to data became easier and turned into a system that brings people together in a single global environment.

Computer systems and the Internet, which are now an indispensable part of everyday life, have incorporated creation and production areas into itself. Castells said, "Mass media is the expression of our culture, and our culture works through the materials provided by mass media." (Castells, 2008: 451). It can be seen that this new technology has a dominance on culture as a unifying and transforming structure today. The fact that it is unifying and transforming means that anyone can be anything. In this common system, the areas of expertise have faded, allowing everyone to be involved, and to be both producers and consumers. Baudrillard drew attention to the importance of responsibility by saying, "We are both the audience, the transmission and the electricity network itself. Everyone has become an integral part of the same reality, the same wheel of responsibility and fate in this universe where there is no distinction between the actor and the audience." (Baudrillard, 2012:131). McLuhan and Powers drew attention to the importance of quality by saying, "As the rate of information exchange accelerates, we will all become more and more involved in the existence of the new robotic corporation, and get lost in it, deprived of the real expertise that has been the stamp of quality of the old private identities. The more information one evaluates, the less he knows. Expertise cannot exist at the speed of light." (McLuhan and Powers, 2001: 209) Gombrich stated that, "There is a reciprocal relationship between the spirit of the age and the art movements. Sometimes the era shapes the art of the time, and in other times art determines the quality of the era." which is quite significant for the relationship between the era and the art. (Gombrich, 1993: 3) Because no matter how the artwork is done, the tools are phenomena of that particular era. The defining effect of the element of art is the aesthetic value it offers.

Art is one of the important elements in the digital-global environment. However, from a more specific point of view, painting has gained a new form in this environment. The fact that almost all areas are a part of the Internet and benefit from computerization has been one of the common subjects in scientific research. According to research conducted with keywords, although art and digitization is a common research topic, it is observed that painting and digitization is a relatively limited research area. Production and consumption have been greatly influenced by speed and in addition to the practices of two-dimensional painting, the practices of three-dimensional painting have also been very popular. However, three-dimensional painting has been excluded from this study, in order to make the study more specific and to focus on the state of two-dimensional painting in more detail. Painting in digital media has been discussed in terms of quality. 


\section{Digitization in Art}

Art is shaped around the diversity of materials and creative environment with the effect of technical means that exist at the time. The creation and presentation of art become cultural phenomena. While social needs determine the development of technology, innovations and differences in production arise in all areas of life. With the emergence of the printing press, production and transmission in oral culture have diversified. It gained another momentum with electronic developments, and a revolutionary period began with the advance of computer and the Internet. Today, in terms of access and production, art has a closer and a faster relationship with the world. Each new communication technology has created a new communication environment. These new environments have diversified the production process. In a study emphasizing that technologies produce meaning regardless of the form and nature, like natural language, visual language, audiovisual language (Bourse and Yücel: 2012: 109), it is stated that technical regulations and frameworks of usage contributed to the creation of meaning and representations. Therefore, as the material and production environment are diversified in art, the meanings change and diversify as well. Art gains a wider form of expression in terms of its language.

Today's communication environment is defined as "new media". New media is a communication system connected to the computer and the Internet. This new communication system is identical to the concept of "multimedia". In general terms, the platform that contains a variety of elements of communication such as data, voice, text, pictures, movies and graphic images is called multimedia. This means that production and distribution can be done in a single medium through a variety of media, and that these media can be brought together. Therefore, more creative production processes can be experienced compared to the past. The most important feature of the new media is digitization. Yengin described digitization as the transfer of analog data to computer-based systems through coding, and explained that the data transferred from the analog system to the computer systems is called digital data. (Yengin, 2012:126) Various applications such as graphics and software have developed with the computer technology. These transformations are an important resource for art as it is now possible to produce artworks with the help of these innovations or using them directly.

Culture and art in the digital environment have started to acquire new forms and shapes. The definition of digital art has now found a clear expression in production, consumption, sharing and distribution channels. So much so that even software and animation are now included in the concept of digital art, and numbers, symbols, virtual forms, expressions and fictional works have been observed to increase in digital art in recent years. (Çokokumuş, 2012:52) Thus, as the area of expertise of the artist expands (as the knowledge of using these systems increases), production becomes more collective (in terms of the diversity of media). As Sağlamtimur explains, the fact that engineers, developers and artists have started to produce artworks by collaborating is an inevitable result of the development of digital technology and the adaptation of the history of contemporary art in the traditional sense to the context of digital art. (Sağlamtimur, 2010: 216) In addition to production, this collaboration affected and transformed distribution and sharing. With the possibilities of multimedia, the need for a physical space to display artworks has started to disappear. Problems like geographical distance and difficulty of access do not exist anymore. Site-specific artworks can only be seen during the opening hours of the venue, while the Internet as a place/environment is always open to visitors, except when a technical problem occurs. In today's world, which can be said to be under the influence of an intense consumer culture, production has to be as fast as possible in order to meet the demand. Nonetheless, the phenomenon of speed is constantly increasing with technological developments. The ability to connect to "anything" miles away in a time span of seconds leads to an excess of information for the human moving from the local to the universal dimension, and makes the issue of "influence" an obligation in terms of production. Consumers aren't influenced by everything they encounter in this dense pool of information, so one needs to be creative and original to be able to influence them.

The source of creativity is art. Fischer believes "art is necessary in order that man should be able to recognize and change the world. But art is also necessary by virtue of the magic inherent in it." (Fischer, 2017: 29) Art has been an important tool in understanding, interpreting and expressing the world in various ways. In the end, the creativity of man/artist could not be embodied without art. The power of art has also been used by sectors as a means for expressing themselves. Additionally, as Bolla emphasizes, "artworks have effects in the world at large, they encode or produce meanings, function as tokens or counters in an economics of exchange... These and other aspects of the objects 
we call artworks will, at different times and for different purposes, be deemed to be as important as aesthetic responses." (Bolla, 2012: 23)

When it comes to new media, the first thing that comes to mind is a combination of artificial memories in a structure where different contents can be uploaded and transferred to different hardware (narrated by Aydın 2011: 105-106 from Törenli, 2005: 157-158). The revolutionary aspect is the fact that various data can now be transferred, processed and reproduced numerically. With the Internet, data transferred to a computer can now be stored without any restriction of time and space, accessed easily and transmitted quickly. Timelessness, placelessness, concurrency, multiple interaction, feedback, and interactivity are some of the important features of the digital system. A large number of people from all over the world can be interacted before, during and after the production and immediate feedback can be obtained. Participatory works can also be produced.

Castells says that the new communication system radically transforms the basic situations in human life in terms of space and time. (Castells, 2008: 501) According to him, local things are culturally, historically and geographically separated from their meaning and form functional networks or collages and reunite. The extent of streaming formats replaces the extent of spaces. The concept of time is erased when the past, the present and the future are programmed to interact with each other in the same message. Therefore, the extent of streams and "timeless time" form the material foundations of a new culture that encompasses and transcends the diversity of historically transmitted representation systems. In other words, according to Castells, a real culture of virtuality emerges where fiction becomes the belief in fiction.

This situation allows different societies to intermingle, learn from each other and introduce their own cultures. This way, the artist's vision is enriched, reflected in his works and he has the chance to introduce himself to different geographical areas more easily. The virtual culture mentioned by Castells can be considered as a common world culture. As a result, since all cultures and societies with Internet access can meet and share the same environment, it is possible to form a common language in terms of expression.

\section{Digitization and Painting}

In the digital environment, art becomes multifaceted by covering various fields, creating a multidisciplinary structure and creating new forms of art. Nowadays digitization is present in almost all fields of art. Çuhacı stated that, from the first graphics using computer technologies to today's advanced virtual environments, all works created in this environment can be evaluated as digital artworks. She mentioned the scope of digital art by saying that "the expansion of the boundaries of digital technologies and traditional art forms (photography, sculpture, painting, etc.), their reproduction and duplication can also be considered digital art." (Çuhacı, 2007: 32) It is also possible to use an image created in a computer environment, for example in the art of ceramics, or to transfer the miniatures to a computer environment and to animate or change their effects. Aside from fields like photography, video and sculpture, it is also possible to use a computer-generated image in ceramics, animate miniature paintings with computer programs, or change their effects. Being able to merge different fields of art and to use digital and analogue in an intertwined fashion enables us to produce more creative and versatile works of art. For instance, it is possible to create new interpretations and effects in painting using photography and graphic design. It is also possible to create 3D or animated works using computer programs.

Samanci stated that the fact that new media is multi-layered carries it far beyond the fact that it is a type of art connected only to the computer system or the Internet. (Samancl, 2014: 52) She also stated that defining the new media in this way would limit it. Because digital production in art can take various forms: The work can be produced directly on the computer, an analogue work can be altered using a variety of digital techniques and applications after being digitized, or a digital work can be transferred to the analogue environment and be altered. As Bozkurt explains, "The image is not only a "reflection", but in the world of "produced-consumed-reproduced" virtual reality, it met with the artist in a new environment in the context of "record-unlimited reproduction-mentality". (Bozkurt, 2005: 29-30) In this respect, the production process has expanded, diversified and many technical possibilities have been available on the same work. In addition, the most important feature of digital media is the option to save and undo at every stage. In this case, the works can be reproduced countless times. The artist can create multi-layered works using the elements of multimedia. For instance, it is possible to create 
a series or a collection, as a single artwork can be saved at different stages with different elements of multimedia and applications. The audience has also gained a more active role, they can alter a digital work online, reproduce and transform it. In this respect, it is remarkable that the digital culture in Samancı's work creates a social space that everyone can participate in by taking over the image production from competent eyes, and this situation brings up the perception that everyone can do everything and succeed. (Samancı, 2014: 49) However, at this point, the involvement of the audience in the art-artist relationship raises a number of discussion topics. There are many questions/problems such as whether the work that the audience intervenes still maintains the status of being a work of art, whether what matters most is the experience, and whether we can talk about the defeat of the work and the loss of its appeal. Or perhaps, as Söylemez emphasizes, the artist did not come up with anything new, and as a result of the contact of the object with the audience, a new type of observer emerged through the media to reproduce and replicate itself with the experiences of the viewer. (Söylemez, 2010: 142) With such an evaluation, it can be considered that it allows the audience to feel the art more deeply by increasing the observation of direct immersion in art.

The perception that new media, which directly addresses the culture of consumption, uses art as a commodity is also on the agenda. An optimistic perspective at this point; is that the buyer/consumer acquires awareness of art or a work of art, which he may not even have been aware of before, and that he may possibly be informed by doing a research. On the other hand, the main issue that has caused controversy is that this situation makes artworks "kitsch".

Although the origin of the word "Kitsch" is uncertain, it is known to be widely used in Germany and Austria in the 19th century. There is an agreement that the word first appeared in the art market of Munich in the 1860s and 1870s and was used to describe cheap and highly sought-after paintings and sketches that were easily marketable. " (Scruton, act: E-skop [Accessed 19.05.2018])

Şahin mentions that kitsch is aimed at general appreciation, it is not considered to have an artistic quality, and puts consumption culture at the axis, says that it is the result of mass production. (Şahin, 2016: 7) He adds that kitsch product is an extension of the capitalist order as a concept which verbalizes objects, and is made up according to the perception of general taste that can be bought cheaply. In this sense; the use of art as a new media object affects the attractiveness of the work. The work of art gains value in terms of its uniqueness. No matter how many copies are made; they cannot approach the value of the original. But they can contribute to the uplifting of the value of the original. On the other hand, as new media is also a creative field, when the producer presents the work differently from his perspective, the work becomes a popular cultural object, which may lead to the object being re-designed (reproduced), making it kitsch. Walter explained this with the loss of the aura:

“(...) [What] withers in the age of mechanical reproduction is the aura of the work of art. (...) The technique of reproduction detaches the reproduced object from the domain of tradition. By making many reproductions it substitutes a plurality of copies for a unique existence. And in permitting the reproduction to meet the beholder or listener in his own particular situation, it reactivates the object reproduced." (Walter 2015: 15)

Returning to the unlimited storage of digital media and the ability to store data forever; it is very easy to transfer the works to future generations as cultural heritage. When we look at the past, many works have survived, but it is clear that there are many works that have disappeared, and even those whose existence is unknown. Since it is difficult to transport a physical work between spaces, it is possible that it will be damaged during transport. Destruction over time is one of the inevitable problems even if museums have efficient conservation methods. However, this cannot be the case for virtual work.

The traditional understanding of painting; the scope of traditional materials such as canvas, brushes, paints have diversified and expanded with technological advances. These advances have opened up new modes of production and new opportunities for the artist, while creating a new area of creativity with a wider perspective, along with new areas of expertise. There is a struggle brought about by a production environment which is based on the specific touch, waiting and completion rules, in which technical and mathematical knowledge comes into prominence rather than the competence in art as stated by Çokokumuş. (Çokokumuş, 2012: 53) As a result, each new development brings new rules, uncertainties, question marks and struggles with the innovations and opportunities it brings. The development of technology, digital media and the Internet has brought applications and sharing 
platforms that allow the production of unlimited copies of artworks, which can be easily redesigned in various ways. In fact, even users with very little technical knowledge can perform these operations. These situations can be thought to wear out the artworks in terms of meaning. Especially artworks with an iconic status encounter these situations more intensively.

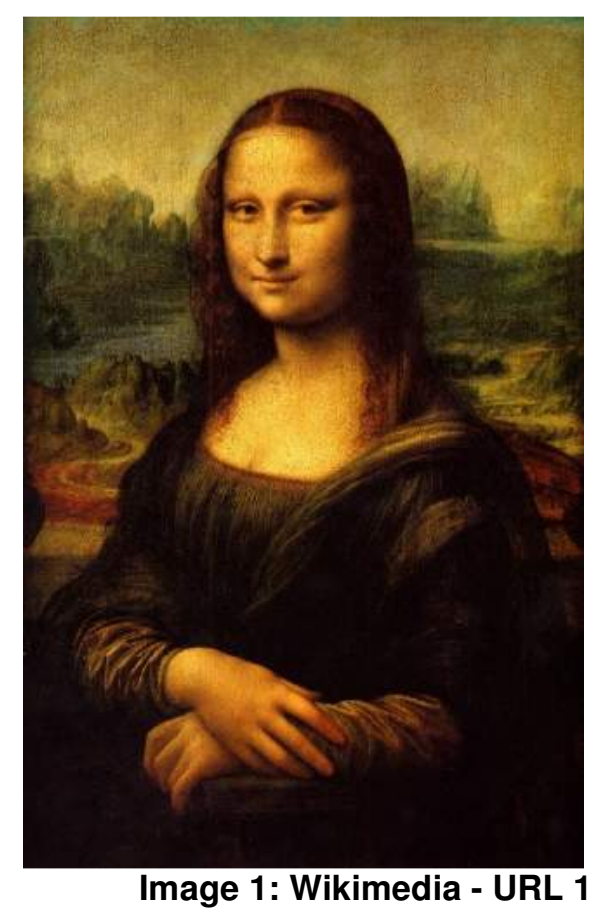

The painting in Image 1 is Leonardo da Vinci's world famous "Mona Lisa". Although the exact date of this 16th century work is not known, it is thought that it was painted around 1505. As a symbol of media of the 20th century, it has found itself in many platforms, from literature and music to advertising. Mona Lisa, one of the world's best-known works, has always influenced artists and still continues to do so. Starting from the painting on canvas, many artists have reproduced this image. Especially with the development of technology and computer systems, Mona Lisa has been redesigned many times for different purposes and subjects.

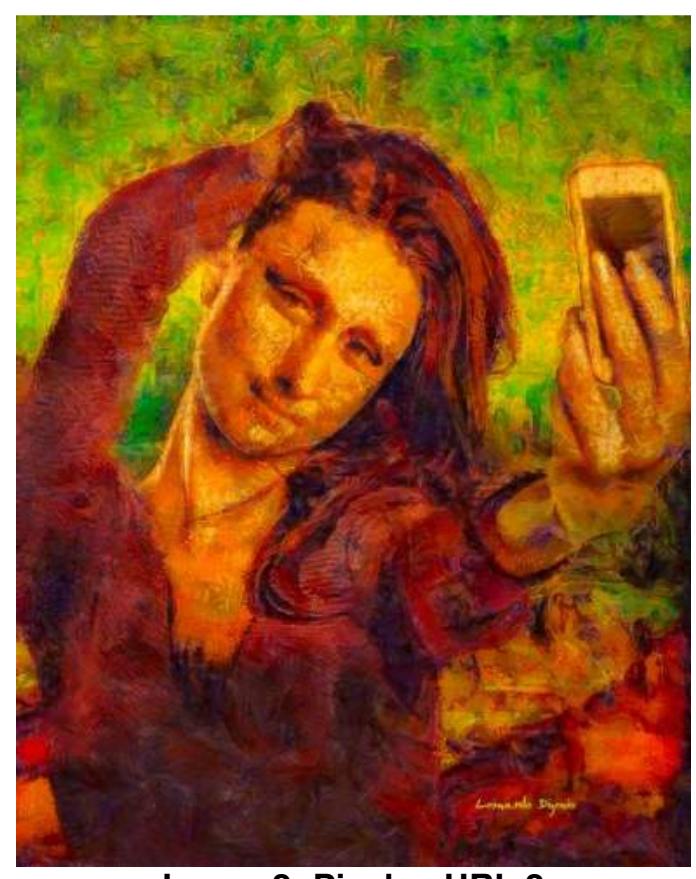

Image 2: Pixels - URL 2 
Leonardo Digenio's "Mona Lisa Selfie" in Image 2 can be given as a very suitable example for both the new media and digital era, as well as the new producer and consumer structure.

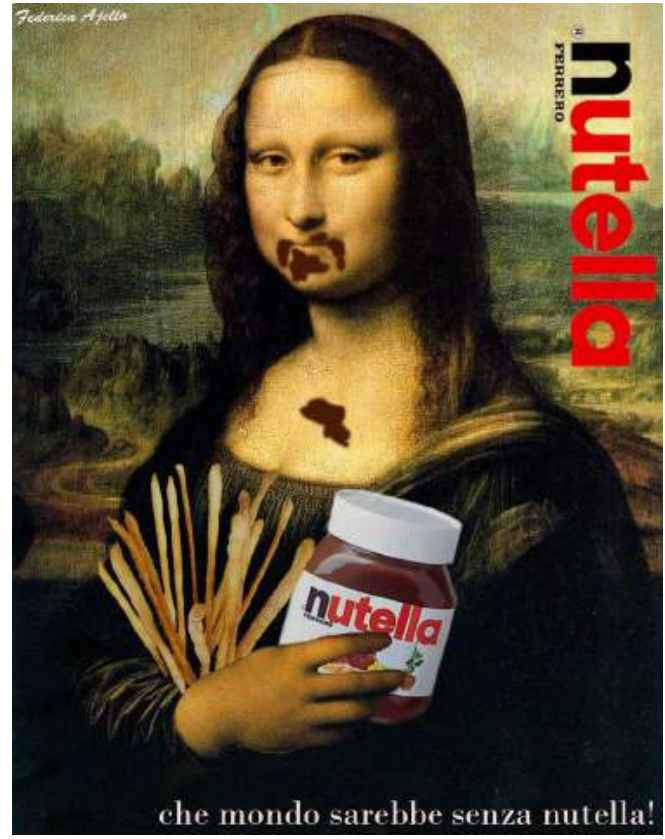

Image 3: Pinterest - URL 3

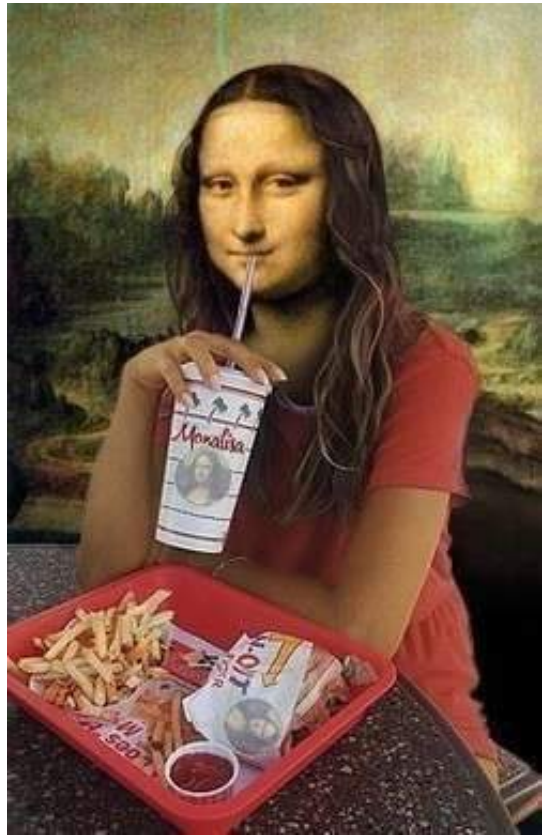

Image 4: Pinterest - URL 4

On the other hand, the intervention of the user to the artworks for various purposes such as advertising, promotion and entertainment can turn the artwork into a kitsch object. Mona Lisa eating dessert and fast food in Images 3-4 may help the artwork to reach a wider audience, but also may lead it to lose its aura.

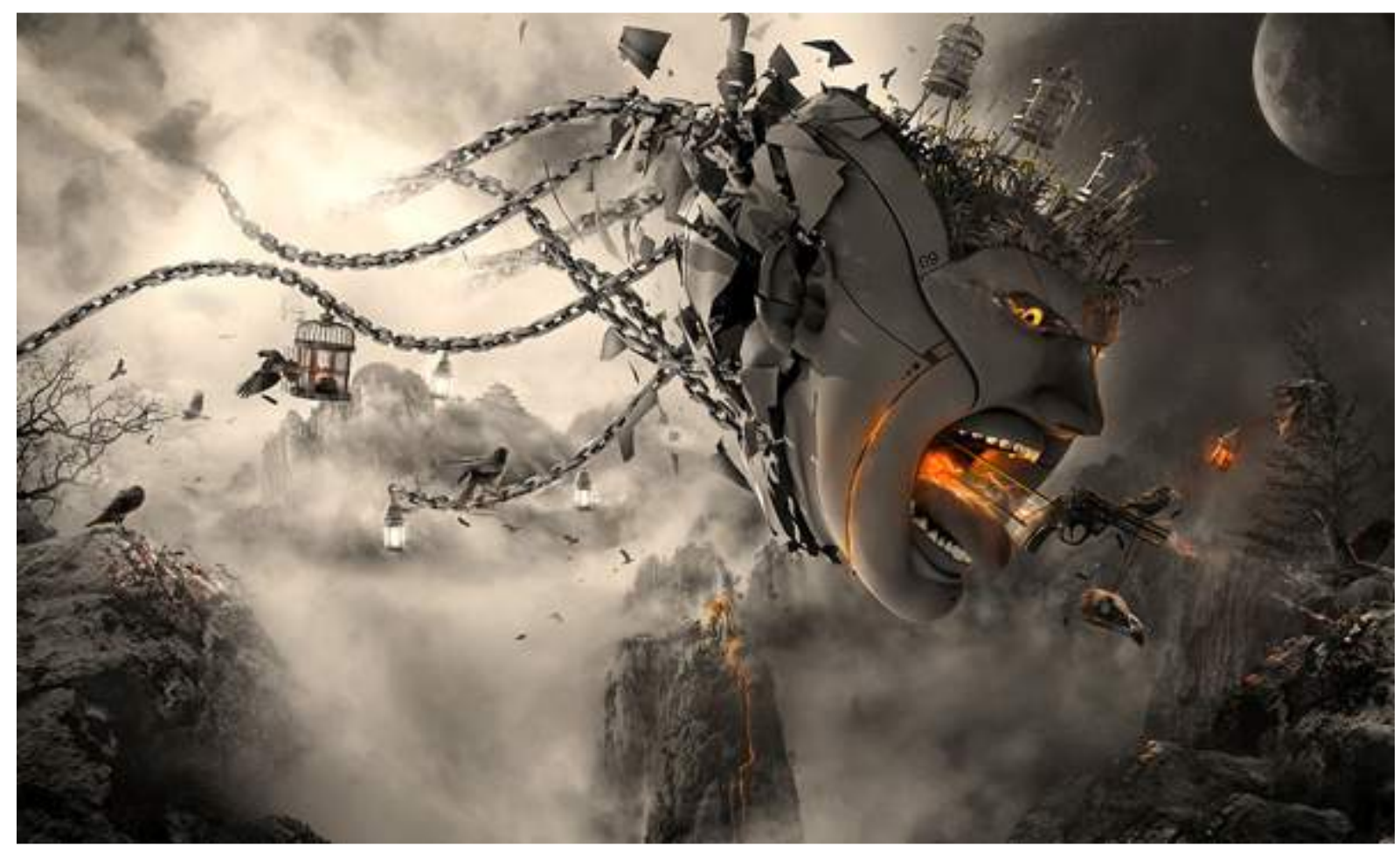

Image 5: Creativeoverflow - URL 5

The work in Image 5 is the work of a young digital artist named Richard Roberts. In an interview he gave to Creative Over Flow [Accessed 03.04.2019], the artist stated that he mostly produced his works in Photoshop and he benefited from photography and digital painting. Therefore, 
when viewed from another point of view, new media opens up new opportunities to be creative, by allowing the producer to work directly within the digital media. The emergence of a different artistic production system and allowing an interdisciplinary diversity with multimedia elements expands the producer's boundaries.

\section{Conclusion}

Painting, one of the oldest and most established branches of art, has interacted with various innovations, media, and technological possibilities of each period, therefore transformed and developed. Innovations have been made in various areas like materials, modes of production, sociocultural environment and society. Computers and the Internet are today's most popular and most useful transfer-sharing environments. Almost all areas of life can now connect to the Internet. Artistic production and sharing has gained a unique momentum with various computer applications and the Internet. Like other branches of art, painting is influenced by this environment. Multimedia has also influenced painting and a multidisciplinary structure has emerged that changes traditional painting habits. In addition to the formation of a collective way of working with computer applications, new areas of expertise have opened up for the artists. Engineers, software developers, graphic designers, artists and experts from many other fields have started collaborating with each other and benefited from each other's fields, thus paving the way for new production and creation processes with a wider perspective for the artists. In general, by allowing users to intervene, digital media makes it possible for everyone to be content creators and be involved in each other's content. But the subject of discussion here is the positive/negative results that might arise from the user/audience intervening in the work (in terms of being closer to art, being more immersed in art, art/artwork losing its appeal, declining quality).

Advertisements in all media outlets are also promoting artworks. However, in addition to all these, it can be assumed that the artworks used in advertisements become objects of popular culture and their effectiveness may decrease. The artwork might become kitsch. On the other hand, with a creative touch, an advertisement can be designed as an artwork as well. Leader, who states that Mona Lisa is the most reproduced artwork in the history of painting, argues that the success of the reproduction of the painting gave the original an interesting status, because numerous copies and versions turned into a mythical, lost object. (Leader, 2018:14) In this respect, how the work is used is very important as it is the main determinant.

Apart from the diversification of production, digital media has other important advantages. By storing the work forever, it can be easily transferred to future generations. Unlimited storage and sharing is possible as a solution to the limitations of physical storage. Problems like time and geographical distance that exist in galleries and museums are eliminated. Certain boundaries between the producer and the consumer no longer exist, thanks to the structure that allows instant sharing, mutual interaction and feedback. The emergence of a new art world is inevitable, in the face of today's most popular medium of the Internet and a society that has an intertwined relationship with it. This situation provides a platform for cultural and inter-communal integration. As the artist and the audience can watch and share artworks all over the world, more investment is made into cultural enrichment. Perhaps this situation will provide a source for the formation of a general world culture/art, in the future without discrimination.

Painting in the context of art in the digital environment may be experiencing the greatest evolution of its history. How this evolution brings important innovations, how it is used, how it is produced and how it is shared can have good or bad outcomes. At the end of the day, technology is a field that can change direction according to its usage. Factors such as the competence of the user, the field of expertise(s), the worldview and the aesthetic view determine the quality of the work.

\section{References}

[1] Aydın, Oya Şakı. (2011). Teknoloji, Haber, Nesnellik -Yeni Medya Tartışma Notları-. İletişim ve Teknoloji. Ed. Zeliha Hepkon. İstanbul: Kırmızı Kedi Yayınevi: 103-120

[2] Aydoğan, Derya. (2014). Türk Romanında Dijitalleşme: E-Kitap. Yüksek Lisans Tezi. İstanbul Kültür Üniversitesi

[3] Baudrillard, Jean (2012). Şeytana Satılan Ruh Ya da Kötülüğün Egemenliği. çev. Oğuz Adanır. İstanbul: Doğu Batı Yayınları.

[4] Bolla, Peter de. (2012). Sanat ve Estetik. Çev. Kubilay Koş. Ayrıntı Yayınları. İstanbul. 
[5] Bourse, Michel. Yücel, Halime. (2012). Illetişim Bilimlerinin Serüveni. İstanbul: Ayrıntı Yayınları

[6] Bozkurt, Muammer. (2005). Video Sanatı Enstelasyon/Film/Performans. İstanbul: Bileşim Yayınevi

[7] Castells, Manuel. (2008). Ağ Toplumunun Yükselişi. 2. bs. İstanbul: İstanbul Bilgi Üniversitesi Yayınları

[8] Çokokumuş, Benan. (2012). Dijital Ortamda Kültür ve Sanat. International Journal of New Trends in Arts, Sports \& Science Education. c. 1. s. 3: 51-66

[9] Çuhacı, Gülüzar. (2007). Dijital Sanatlarda Bedenin Kullanımı. Doktora Tezi. Marmara Üniversitesi İletişim Bilimleri Anabilim Dalı

[10] Fischer, Ernst. (2017). Sanatın Gerekliliği. çev. Cevat Çapan. Sözcükler Yayınları. İstanbul.

[11] Gombrich, Ernst. H. (1993). Sanatın Öyküsü. çev. B. Cömert. İstanbul: Remzi Kitapevi Yayınları.

[12] McLuhan, Marshall. Powers, Bruce R. (2001). Global Village: İstanbul: Scala Yayıncılık.

[13] Sağlamtimur, Zühal Özel. (2010). Digital Art. Anadolu University Social Science Journal. c. 10. s. 3: $213-238$

[14] Samancı Menekşe. (2014). Image as Art Production Environment. Master Thesis. YTÜ Institute of Social Science.

[15] Scruton, Roger. (2015). Kitsch'in Dayanılmaz Çekiciliği. Çeviri: Ayşe Boren. E-skop Sanat Tarihi Eleştiri Online Dergisi. <http://www.e-skop.com/skopbulten/kitschin-dayanilmazcekiciligi/2273> [Accessed 19.05.2018]

[16] Söylemez, Meltem. (2010) Yeni Medya Sanatı ve Kuramsal Açılımlar. Atatürk Üniversitesi Institute of Fine Arts Dergisi: c. 0 s. 24: 137-146.

[17] Şahin, Hikmet. Sanatta Kitsch Olgusu Üzerine. Akdeniz Sanat Dergisi. c.9, s.17.

[18] Yaylagül, Levent. (2013). Kitle İletişim Kuramları, Ankara: Dipnot yayınları.

[19] Yengin, Deniz. (2012). Yeni Medyaya Eleştirel Bakış. Yeni Medya ve... ed. Deniz Yengin. İstanbul: Anahtar Kitaplar: 123-133

[20] Walter, Benjamin. (2015). Teknik Olarak Yeniden Üretilebilirlik Çağında Sanat Yapıtı. çev. Gökhan Sarı. Zeplin Kitap. İstanbul.

[21] Leader, Darian. (2018). Mona Lisa Kaçıııldı Sanatın Bizden Gizledikleri. Ayrıntı Yayınları. İstanbul.

[22] URL 1 https://commons.wikimedia.org/wiki/File:Mona_Lisa.jpg [Accessed 5.03.2019]

[23] URL 2 https://pixels.com/featured/mona-lisa-selfie-da-leonardo-digenio.html [Accessed 31.03.2019]

[24] URL 3 https://tr.pinterest.com/pin/585608757771076367/ [Accessed 31.03.2019]

[25] URL 4 https://tr.pinterest.com/pin/7388786874572960/ [Accessed 31.03.2019]

[26] URL 5 https://creativeoverflow.net/interview-with-richard-roberts-digital-artist/ [Accessed 3.04.2019] 